\title{
Leslibetaeus coibita, n. gen., n. sp., a new alpheid shrimp from the Pacific coast of Panama (Crustacea: Decapoda)
}

\author{
ARTHUR ANKER $^{1}$, DENIS PODDOUBTCHENKO $^{1} \&$ INGO S. WEHRTMANN ${ }^{2}$ \\ ${ }^{1}$ Smithsonian Tropical Research Institute, Naos Unit 0948, APO AA 34002-0948, USA. \\ Email: ankera@si.edu,poddoubtchenkod@si.edu \\ ${ }^{2}$ Escuela de Biología, Universidad de Costa Rica, San José 2060, Costa Rica. Email: ingowehrtmann@gmx.de
}

\begin{abstract}
A new alpheid shrimp, Leslibetaeus coibita, n. gen., n. sp., is described on the basis of two specimens extracted from crevices in a shale rock on the rocky intertidal shore in the Isla Coiba National Park, Pacific coast of Panama. Leslibetaeus is characterized by absence of rostrum and orbital teeth; eyes being only partially covered by carapace; sixth abdominal somite without articulated plate; first segment of the antennular peduncle without tooth on ventromesial carina; short scaphocerite; tip of third maxilliped with stout spines; and strap-like epipods present on third maxilliped and first to fifth pereiopod; stout symmetrical chelipeds, with carpus distally strongly lobed and bearing two rows of setae mesially, and chela without snapping mechanism; carpus of second pereiopod five-segmented, with second segment distinctly longer than first; ischium and merus of third pereiopod unarmed. The new genus appears to be relatively basal and not closely related to any of the currently described alpheid genera. The finding of this new taxon in a relatively accessible habitat indicates a yet unexplored biological potential of the Isla Coiba National Park.
\end{abstract}

Key words: Alpheidae, new genus, new species, Panama, eastern Pacific, rocky intertidal

\section{Introduction}

The alpheid fauna of the eastern Pacific consists of 13 genera (Table 1) with almost 100 species ranging from southern Alaska to Cape Horn. The vast majority of species are concentrated in the subtropical and tropical waters, from the northern Gulf of California south to northern Peru and the Galápagos Islands. The Pacific coast of the Republic of Panama presents a high diversity of marine habitats, and may be one of the major hotspots of alpheid and other marine species diversity in the eastern Pacific. Surprisingly, only four genera, viz. Alpheus Fabricius, 1798, Synalpheus Bate, 1888, Automate De Man, 1888 and 
Pomagnathus Chace, 1937, have been previously reported from the Pacific coast of this country (e.g., Wicksten, 1981, 1983, 1993; Kim \& Abele, 1988; Abele \& Kim, 1989).

In March 2005, Leslie Harris (Natural History Museum of Los Angeles County, Los Angeles, USA) and one of the authors (IW) made a preliminary sampling of intertidal and subtidal crustaceans and polychaetes on Isla Uva and Isla Coibita (a tiny island off Isla Ranchería) in Isla Coiba National Park, Golfo de Chiriqui, western Panama. The intertidal shrimp collection contained two specimens (male and female) of a peculiar alpheid with stout, equal-sized and shaped chelipeds, frontal region without rostrum and orbital teeth, and sixth abdominal somite lacking a posteroventral articulated plate. These specimens represent an undescribed genus and species, which is described herein.

TABLE 1. Alpheid genera previously reported from the eastern Pacific. The number of species includes both described and presently known undescribed species.

\begin{tabular}{|c|c|c|}
\hline Genus & $\begin{array}{l}\text { Number } \\
\text { species }\end{array}$ & f References \\
\hline Alpheopsis Coutière & 6 & $\begin{array}{l}\text { Wicksten \& Hendrickx 1986; Wicksten 1992; Ríos } \\
\text { 1992; A. Anker, pers. obs. }\end{array}$ \\
\hline $\begin{array}{l}\text { Alpheus Fabricius } \\
\text { (synonym: Thunor Banner) }\end{array}$ & $>50$ & $\begin{array}{l}\text { Holthuis 1980; Wicksten 1983; Christoffersen } \\
\text { \&Ramos 1987, 1988; Kim \& Abele 1988; Wicksten } \\
\text { 1988; Ramos \& Von Prahl 1989 Carvacho 1989; Abele } \\
\text { \& Kim 1989; Wicksten 1990; Knowlton \& Mills 1992; } \\
\text { Wicksten 1993; Wicksten 1994b; Ramos 1997; } \\
\text { McClure \& Wicksten } 2000\end{array}$ \\
\hline Automate De Man & 2 & Coutière 1900; Boone 1931; Wicksten 1981 \\
\hline Betaeus Dana & 9 & Holthuis 1952; Hart 1964 \\
\hline Coronalpheus Wicksten & 1 & Wicksten, 1999 \\
\hline Leptalpheus Williams & at least 4 & Ríos \& Carvacho 1983b; Felder et al. 2003 \\
\hline Metalpheus Coutière & 1 & Chace 1962 \\
\hline $\begin{array}{l}\text { Notalpheus Méndez \& } \\
\text { Wicksten }\end{array}$ & 1 & Méndez \& Wicksten 1982 \\
\hline $\begin{array}{l}\text { Parabetaeus Coutière } \\
\text { (synonym: Neoalpheopsis } \\
\text { Banner) }\end{array}$ & 1 & Wicksten 1983, 1993 \\
\hline Pomagnathus Chace & 1 & Chace 1937; Wicksten 1983 \\
\hline $\begin{array}{l}\text { Prionalpheus Banner \& } \\
\text { Banner }\end{array}$ & 1 & Alvarez et al. 1996 \\
\hline Salmoneus Holthuis & 2 & Wicksten 1983, 1993; Ríos \& Carvacho 1983a \\
\hline Synalpheus Bate & $>20$ & $\begin{array}{l}\text { Coutière 1909; Holthuis 1952; Abele 1975; Wicksten } \\
\text { 1983, 1989, 1993; Abele \& Kim 1989; Ríos 1992; } \\
\text { Wicksten 1994a; Hermoso-Salazar et al. } 2005\end{array}$ \\
\hline
\end{tabular}


The material was collected at low tide on a rocky shore of Isla Coibita, Isla Coiba National

Park, Pacific coast of Panama. Intertidal rocks were broken apart and animals were extracted with a forceps from crevices and later preserved in $70 \%$ ethanol. Some specimens (including the holotype of the new species described below) were photographed alive prior to preservation. All drawings were made using a dissecting microscope and a camera lucida. Carapace length (CL) and total length (TL) were measured from the tip of the frontal margin to the posterior margin of the carapace and telson, respectively. All specimens are deposited in the Crustacean Collection, Natural History Museum of Los Angeles County, Los Angeles, USA (LACM).

\section{Leslibetaeus, n. gen.}

Body moderately stout. Frontal margin rounded, without rostrum and orbital teeth. Pterygostomial angle rounded, not protruding. Eyes partly concealed in dorsal and lateral view, visible in frontal view; cornea well developed. Antennular peduncle moderately slender; first segment without ventromesial tooth; lateral antennular flagellum with poorly developed secondary ramus. Antenna with basicerite robust; carpocerite short, reaching far beyond scaphocerite. Mouthparts typical for family; mandible with bisegmented palp and well developed molar and incisor processes. Third maxilliped pediform, lateral plate feebly developed, rounded; tip of ultimate segment with stout spines. Chelipeds enlarged, equal in size, symmetrical in shape, robust, carried extended; ischium with spines on dorsodistal margin; merus ventrally flattened; carpus very stout, cup-shaped, with strong distal lobes, with two comb-like rows of setae mesially; chela stout, inflated; palm smooth, linea impressa and adhesive discs absent; cutting edges of fingers with teeth, without snapping mechanism. Second pereiopod with five-segmented carpus, second segment longest. Third pereiopod with ischium lacking spine; merus unarmed; carpus with distoventral spine; propodus with slender spines on ventral margin; dactylus simple. Sixth abdominal somite without articulated plate at posterolateral angle. Second pleopod with appendix interna and appendix masculina. Uropod with sympodite bearing subacute tooth; diaeresis with broad subacute tooth in mid-portion. Telson with two pairs of dorsal spines and two pairs of posterolateral spines, lateral much shorter and directed upwards; posterior margin reduced; anal tubercles absent. Gill/exopod formula: 5 pleurobranchs (P1-5); 1 arthrobranch (Mxp3); 0 podobranch; 2 lobe-shaped epipods (Mxp1-2); 5 strap-like epipods or mastigobranchs (Mxp3, P1-4); 5 setobranchs (P1-5); 3 exopods (Mxp1-3).

Type species. - Leslibetaeus coibita, $\mathrm{n}$. sp., by monotypy and present designation.

Etymology. - We are more than pleased to dedicate this genus to our dear colleague and one of the collectors of this shrimp, Leslie Harris. The generic name is a combination of the collector's first name, Leslie, and betaeus, referring to the superficial resemblance 
of the new genus to the alpheid genus Betaeus Dana, 1852 (see below). Gender masculine.

Remarks. - See below.

\section{Leslibetaeus coibita, n. sp.}

Material examined. - Holotype: LACM CR 2005-013.2, 1 female (CL 3.4 mm), Isla Coibita, on side facing Isla Coiba, north side of Smithsonian Tropical Research Instititute

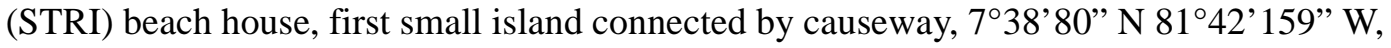
Isla Coiba National Park, Pacific coast of Panama, extracted by hand/forceps from crevice of a shale rock, coll. L. Harris \& I.S. Wehrtmann, 12 March 2005. Paratype: LACM CR 2005-013.1. 1 male (CL $3.2 \mathrm{~mm}$ ), same data as for holotype [specimen poorly preserved, broken in two parts, most appendages dissected].

Description. - Body moderately elongated (Fig, 1), not particularly compressed. Carapace smooth, with very shallow, poorly defined grooves on flanks, without sutures, glabrous except for minute, scarce, erect setae; anterior portion somewhat inflated in lateral view (Fig. 1); pterygostomial angle rounded, not protruding (Fig. 2b); branchiostegial margin with a few setae; cardiac notch well developed (Fig. 2c); frontal margin of carapace broadly rounded (Fig. 2a), rostrum and orbital teeth absent. Eyes partly concealed, anterior portion visible in dorsal and lateral view (Fig. 2a, b), without tubercles or spines, cornea moderately developed. Ocellar beak not conspicuous. Epistomial sclerite without acute projection.

Antennular peduncle not particularly stout, moderately elongated, slender (Fig. 2a); first segment with stylocerite somewhat apressed, reaching distal margin of first segment, distally subacute (Fig. 2a, d), ventromesial carina unarmed (Fig. 2d, e), dorsomesial surface proximal to eye with one-two small spines (Fig. 2a, e); second segment subequal to visible portion of first segment, much longer than third segment; lateral flagellum with secondary ramus reduced to a small knob with one (male) or two (female) tufts of aesthetascs, latter longer and more numerous developed in female (Fig. 2b, d, e), proximal fused portion composed of five-six segments. Antenna with basicerite relatively stout, armed with strong ventrolateral tooth (Figs. 2b, 3b); scaphocerite subrectangular, short, reaching only slightly beyond half length of carpocerite, anterior margin of blade convex, not extending beyond distolateral tooth (Figs. 2a, 3b); carpocerite robust, elongated (Fig. 3a); tubercle of antennal gland not protruding.

Mouthparts typical for family. Mandible with bisegmented palp; molar process slightly broadened distally (Fig. 3c); incisor process distally with five-six subtriangular teeth (Fig. 3d, e). Maxillule with palp bilobed, dorsal lobe with one seta, ventral lobe with several setae (Fig. 3f). Maxilla with scaphognathite narrow (Fig. 3g); endopod small, not segmented; dorsal endite not deeply notched (Fig. 3g); ventral endite with elongated setae. First maxilliped with caridean lobe on exopod narrow, with a few setae (Fig. 3h); endopod not segmented, with elongated setae distally; epipod relatively small, oval to subtriangular. 
Second maxilliped with small oval-rounded epipod (Fig. 3i); endopod without specific features; exopod somewhat broadened proximally. Third maxilliped pediform, elongated but stout (Fig. 3j); coxa with lateral plate feebly developed, ear-shaped, without acute projections (Fig. 31, m), mesial surface with row of spinules (Fig. 3m); antepenultimate segment somewhat broadened, triangular in cross section; penultimate segment about twice as long as wide (Fig. 3j); ultimate segment tapering distally, dorsal margin with short spines or spiniform setae, tip with two stout subterminal spines and one stout terminal spine (Fig. 3k); exopod reaching 3/4 length of antepenultimate segment (Fig. 3j); arthrobranch well developed.

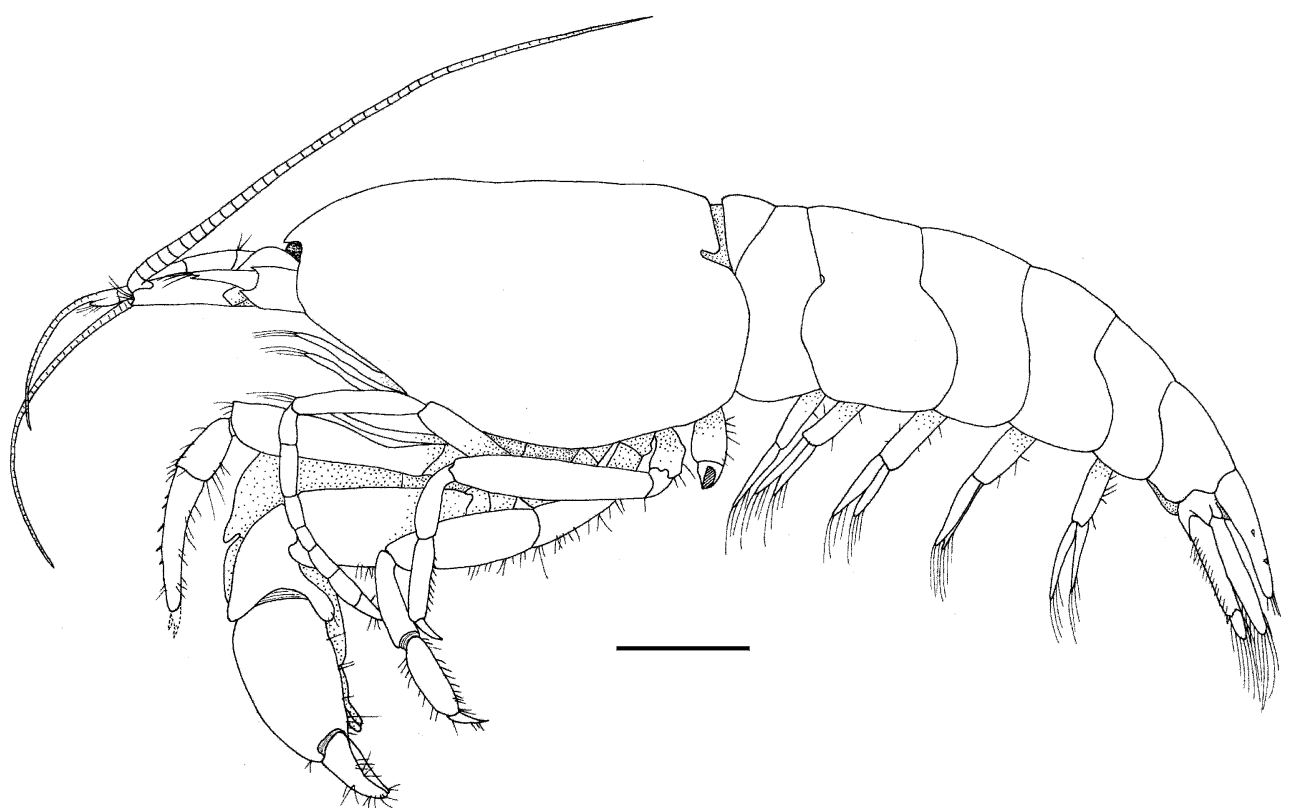

FIGURE 1. Leslibetaeus coibita, n. gen., n. sp. Holotype, female (LACM CR 2005-013.2): habitus. Scale $1 \mathrm{~mm}$.

Chelipeds equal in size, symmetrical in shape, carried extended, robust (Fig. 4a, b); coxa robust, with row of spinules ventromesially (Fig. 4h); basis small, with tuft of stiff setae mesially; ischium very stout, dorsal margin distally produced and furnished with two-three stout spines (Fig. 4c, h, i); merus stout, flattened ventrally, distolateral margin with rounded lobe; carpus very stout, cup-shaped, distal margin with several rounded lobes - one dorsolateral, one dorsomesial and one, particularly developed, ventral lobe, latter partially embracing palm (Fig. 4a, b, d, e, h); mesial face with two comb-like rows of setae (Fig. 4d, g); chela relatively short, inflated; palm smooth, linea impressa and adhesive discs absent; fingers stout, slightly more than half length of palm (Fig. 4e, g-j), slightly gaping when closed; cutting edge of dactylus unarmed, with hiatus anterior to mid-portion (Fig. 4e, h-j); cutting edge of pollex armed with blunt tooth opposed to hiatus, and with 


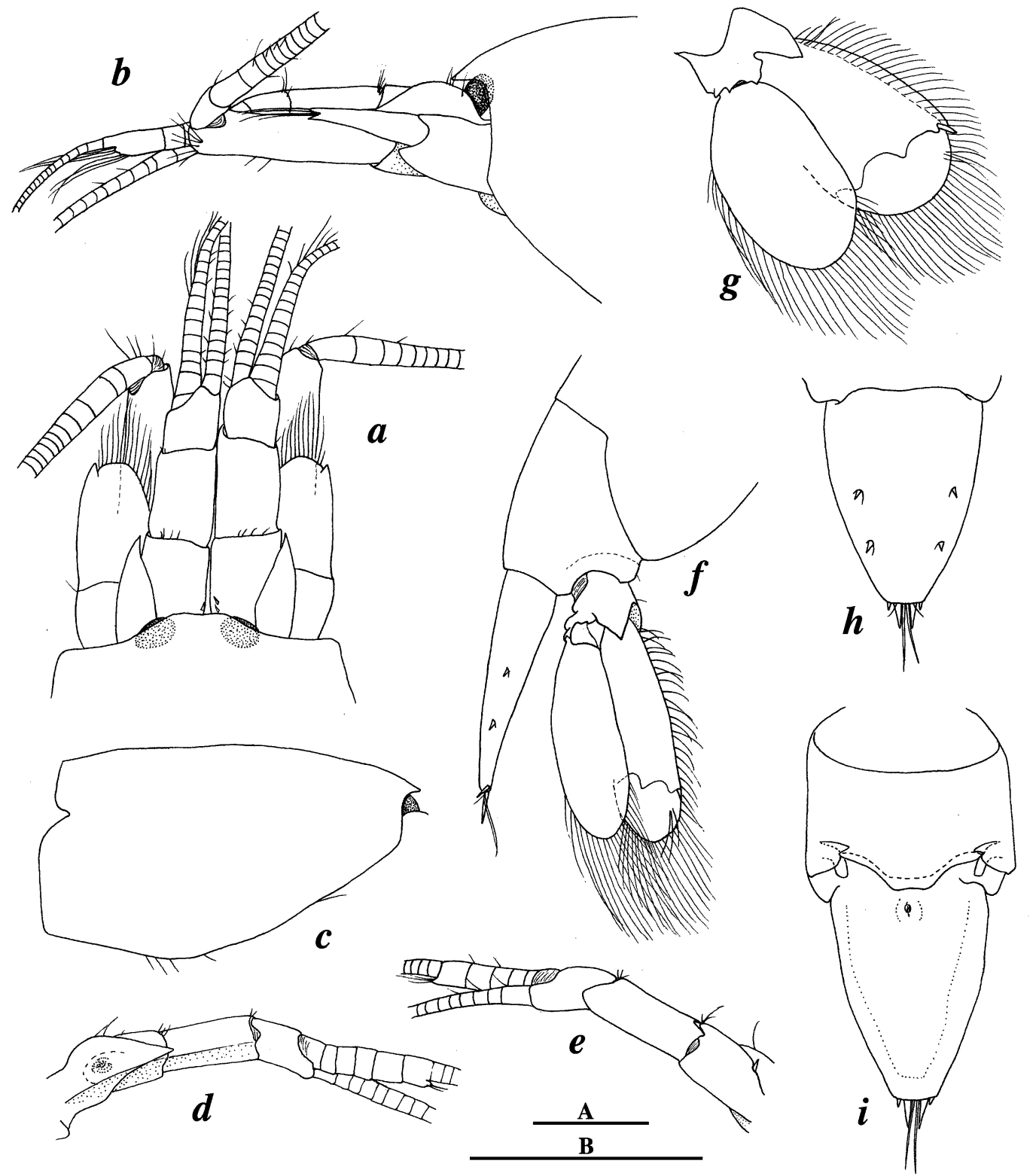

FIGURE 2. Leslibetaeus coibita, n. gen., n. sp. Holotype, female (LACM CR 2005-013.2) (a, b) and paratype male (LACM CR 2005-013.1) (c-i), a — frontal region, dorsal view; b — same, lateral view; c - carapace, lateral view; d - antennule, lateral view; e - same, mesial view; $\mathrm{f}$ posterior region of abdomen and telson, lateral view; $\mathrm{g}$ - uropod, dorsal view; $\mathrm{h}$ - telson, dorsal view; $\mathrm{i}$ - telson and sixth abdominal somite, ventral view. Scale $1 \mathrm{~mm}$ (A: c, B: a, b, d-i). 


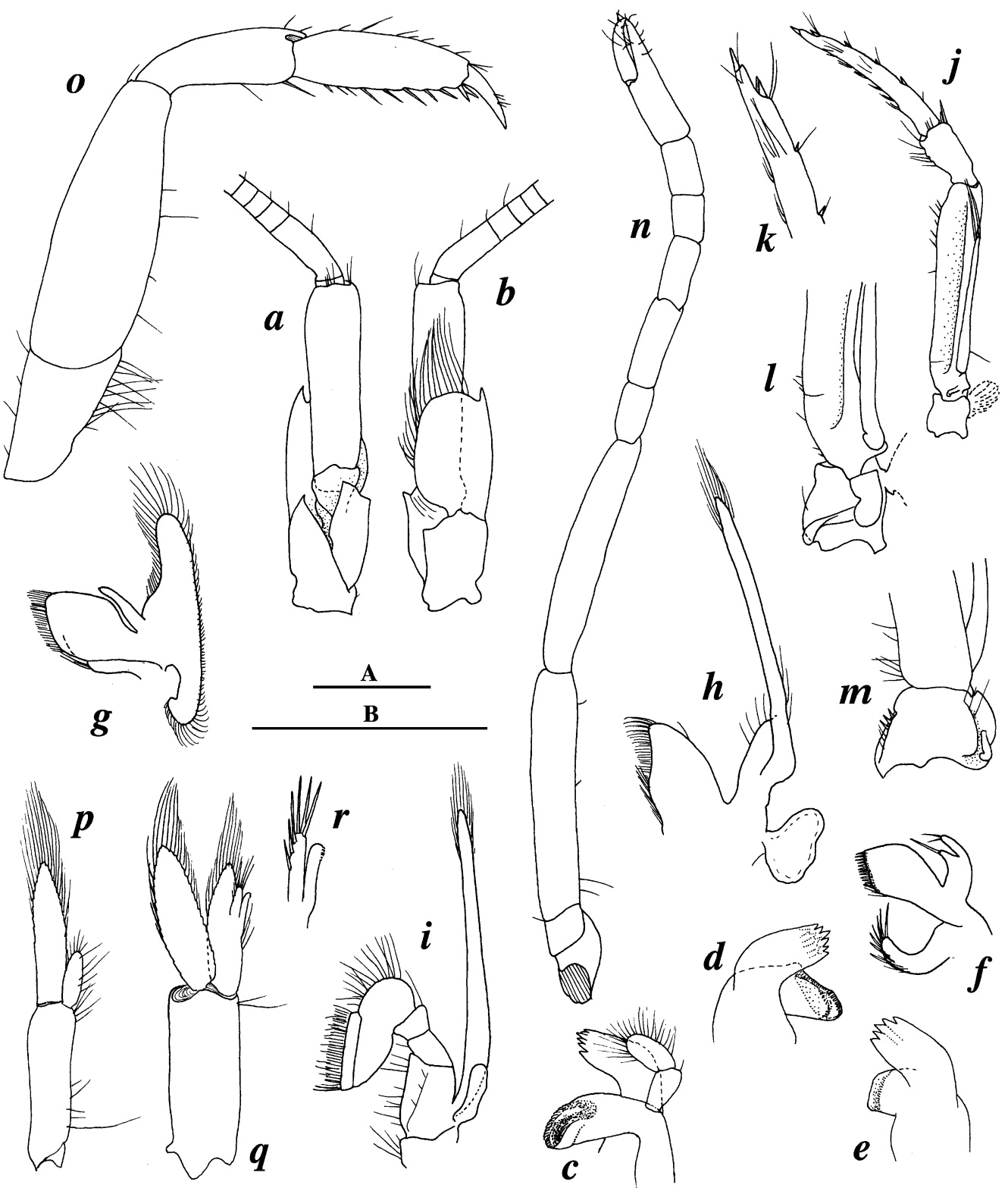

FIGURE 3. Leslibetaeus coibita, n. gen., n. sp. Holotype, female (LACM CR 2005-013.2) (p) and paratype male (LACM CR 2005-013.1) (a-o, q, r), a — antenna, ventral view; b - same, dorsal view; c — right mandible, mesial view; d — same, lateral view (palp detached); e — left mandible, lateral view (palp detached); $\mathrm{f}$ - maxillule, lateral view; g - maxilla, lateral view; $\mathrm{h}$ - first maxilliped, lateral view; $\mathrm{i}$ - second maxilliped, lateral view; $\mathrm{j}$ - third maxilliped, lateral view (arthrobranch detached, position indicated); $\mathrm{k}$ — same, tip of ultimate segment, lateral view; 1 same, proximal region, lateral view; $\mathrm{m}$ - same, ventrolateral view; $\mathrm{n}$ - second pereiopod, lateral view; o - third pereiopod, lateral view; $\mathrm{p}$ - first pleopod, mesial view; $\mathrm{q}$ - second pleopod, mesial view; $\mathrm{r}$ - same, detail of appendices externa and interna. Scale $1 \mathrm{~mm}(\mathrm{~A}: \mathrm{j}, \mathrm{B}$ : $\mathrm{a}-\mathrm{h}, \mathrm{k}$; $\mathrm{r}$ drawn without scale). 


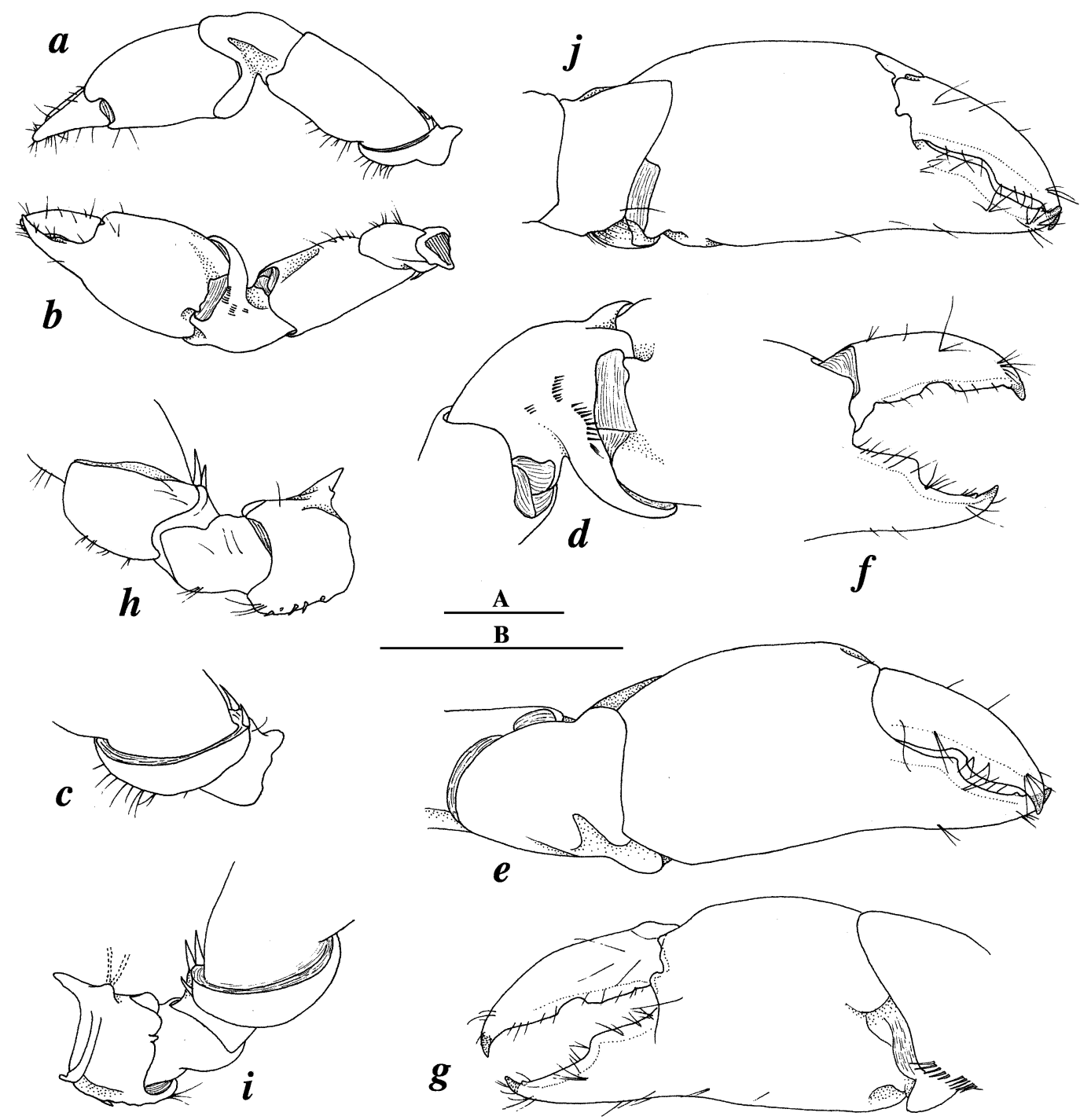

FIGURE 4. Leslibetaeus coibita, n. gen., n. sp. Paratype male (LACM CR 2005-013.1): chelipeds, a - left cheliped, lateral view; b - same, mesial view; $\mathrm{c}$ - same, ischium and basis, lateral view; $\mathrm{d}$ - same, carpus, mesial view; e - same, chela and carpus, lateral view; $\mathrm{f}$ - same, chela fingers open, lateral view; $\mathrm{g}$ - same, mesial view; $\mathrm{h}$ - right cheliped, coxa to proximal merus, mesial view; $\mathrm{i}$ - lateral view; j - same, chela, lateral view. Scale $1 \mathrm{~mm}$ (A: a, b, B: c-j).

Second pereiopod slender; ischium subequal to merus; carpus with five segments, second longest, segment length ratio approximately equal to $1: 1.5: 1.2: 0.8: 1$ (Fig. 3n); chela simple, fingers slightly shorter than palm, with tufts of setae. Third pereiopod with all endopodal articles strongly compressed; ischium without ventrolateral spine, with row of stiff setae ventrally (Fig. 3o); merus broadened, dorsal and ventral margins slightly convex, unarmed; carpus distinctly shorter and narrower than merus, with stiff seta 
ventrodistally (Fig. 3o); propodus subequal in length and width to carpus, with about six slender spines on ventral margin and pair of stouter distoventral spines adjacent to dactylus (Fig. 3o); dactylus simple, moderately slender, slightly curved, about 1/3 length of propodus, furnished with setae (Fig. 3o). Fourth pereiopod similar to third, but distinctly more slender (Fig. 1). Fifth pereiopod unknown (missing on both sides in holotype and paratype).

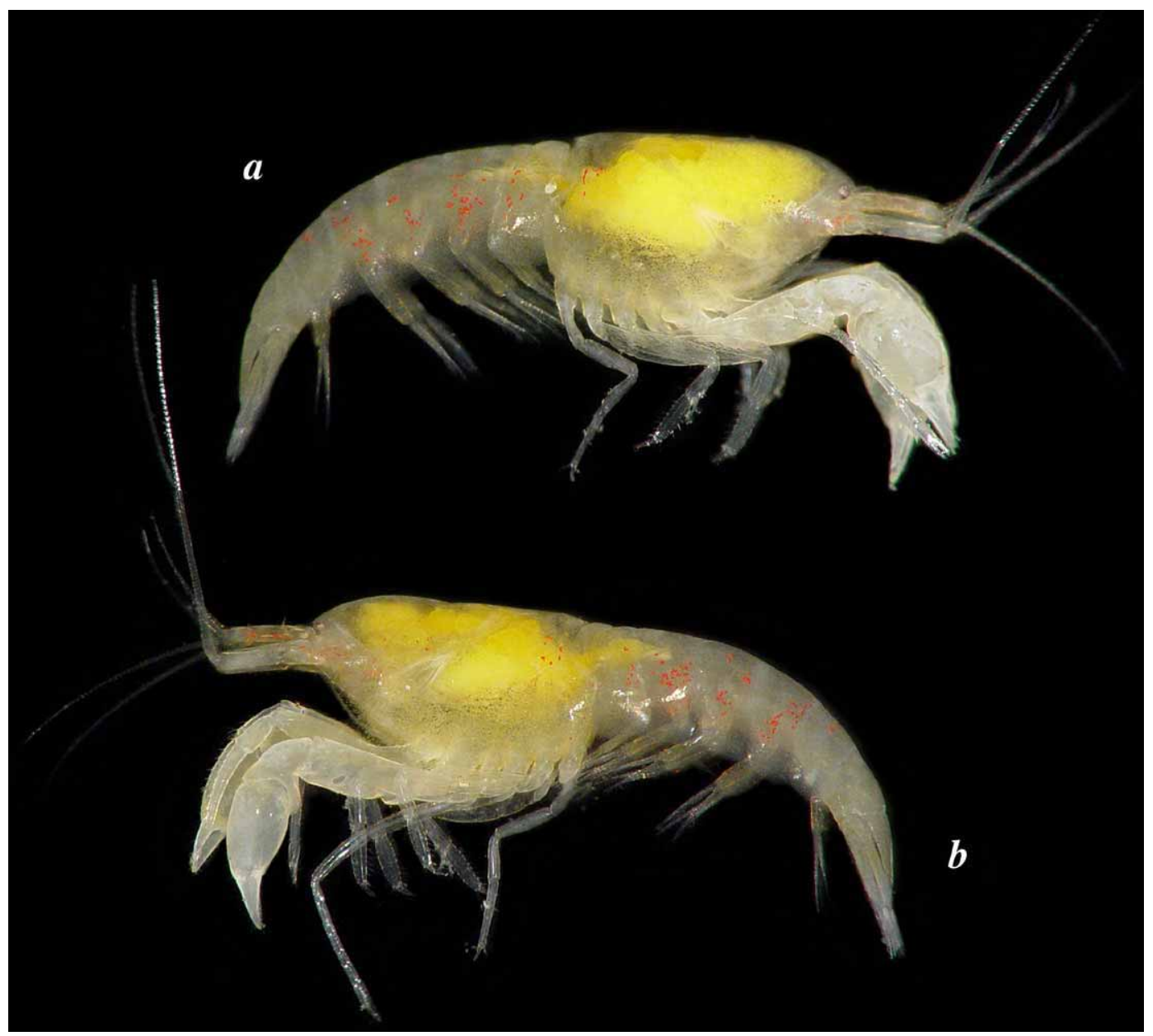

FIGURE 5. Leslibetaeus coibita, n. gen., n. sp. Holotype, female (LACM CR 2005-013.2): colour pattern, a - right side; $\mathrm{b}$ - left side. Photograph by Leslie Harris.

Abdominal somites I-V with posterolateral angles of pleura rounded (Fig. 1); sixth somite rounded posteriorly and without distinct articulated plate at ventroposterior angle (Fig. 2f); preanal plate slightly projecting posteriorly, subrectangular (Fig. 2i). First pleopod with endopod less than half length of exopod, oval, fringed with setae (Fig. 3p). Male second pleopod with appendix masculina short, slightly longer than appendix 
interna, with three-four slender setae on apex and three setae along mesial margin (Fig. 3q, r); female second pleopod with appendix interna only. Uropods slightly exceeding telson (Fig. 2f); lateral lobe of sympodite distally acute (Fig. 2g); endopod and exopod subequal in length; exopod with diaeresis bearing three teeth - one small triangular tooth near distolateral spine, one broad subacute tooth in mid-portion and one broadly rounded tooth closer to mesial margin (Fig. 2g); distolateral spine relatively small but robust (Fig. 2g). Telson broad, tapering distally, subtriangular, about 1.5 times as long as wide proximally, with lateral margins convex (Fig. 2h); proximal width about five times width of posterior margin; dorsal surface with two pairs of small spines situated at some distance from lateral margin, one pair at mid-length, another pair at distal $1 / 3$ of telson length (Fig. 2h); posterior margin reduced, straight, with two pairs of posterolateral spines, lateral much shorter than mesial and directed upwards (Fig. 2f, h), median portion between mesial spines with two long, non-plumose setae and two shorter setae departing obliquely (missing in one specimen); anal tubercles absent (Fig. 2i). Gill/exopod formula as given for genus.

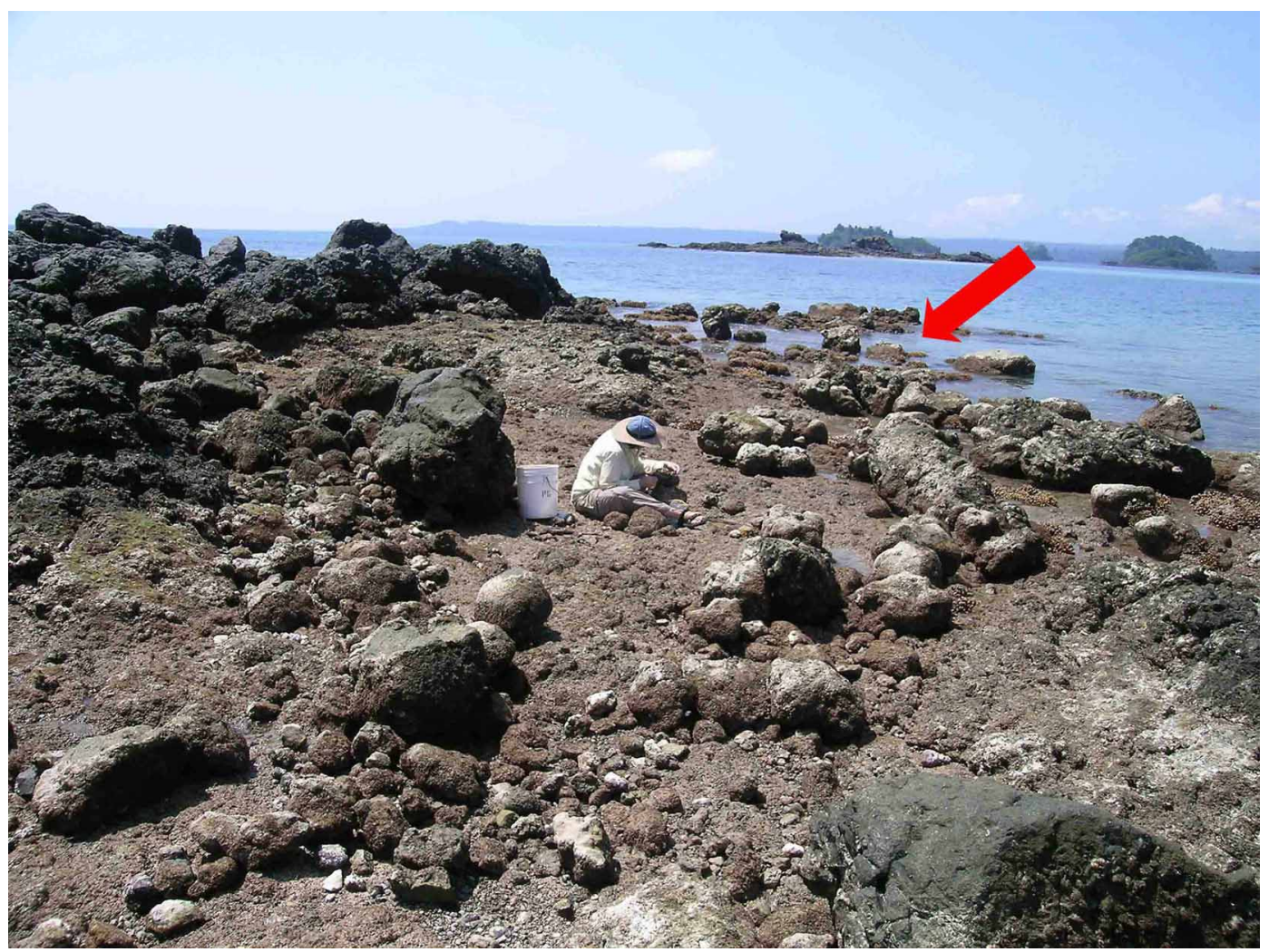

FIGURE 6. Locality of collection of Leslibetaeus coibita, n. gen., n. sp., intertidal rocky shore on Isla Coibita, Isla Coiba National Park, Panama, with Leslie Harris extracting animals from rock crevices. The red arrow indicates approximate position of the shale rock where the two specimens of Leslibetaeus coibita, n. gen., n. sp. were found. 
Colour. - Semitranslucent with grey tinge; anterolateral and posterolateral portions of carapace, lateral portions of the first five abdominal somites, antennular peduncle and basicerite of antenna with bright red chromatophores; chelae hyaline whitish; cornea brown; ovaries bright yellow (Fig 5).

Size. - Small sized alpheid, with CL ranging from $3.2 \mathrm{~mm}$ in male to $3.4 \mathrm{~mm}$ in female, latter with TL of $9.1 \mathrm{~mm}$.

Etymology. - The name of the new species refers to the type locality, Coibita, a small island off Isla Ranchería in the Isla Coiba National Park. Coibita is here used as a noun in apposition.

Ecology. - The holotype specimens of Leslibetaeus coibita, n. gen., n. sp. were collected at low tide on the rocky mid-intertidal (Fig 6), from crevices of a large shale rock. It is noteworthy that the bedrock and most loose rocks in the area were basaltic (L. Harris, pers. comm.).

Distribution. - Presently known only from the type locality: Isla Coibita, Isla Coiba National Park, Golfo de Chiriqui, Pacific coast of Panama.

Remarks. - Leslibetaeus, n. gen. is defined by the combination of several features: the frontal margin of the carapace without orbital teeth and distinct rostrum; the incomplete orbital hoods, only partially concealing the eyes; the sixth abdominal somite without articulated plate; the symmetrical stout chelipeds, with ischium bearing spines dorsally, carpus distally strongly lobed and bearing two comb-like rows of setae mesially, and short, smooth chela, without snapping mechanism on the finger cutting edges; the carpus of the second pereiopod five-segmented, with second segment distinctly longer than first; the ischium and merus of the third pereiopod without spines, ischium with a row of setae ventrally; the first segment of the antennular peduncle without tooth on the ventromesial carina; the scaphocerite being only half as long as carpocerite; the tip of the third maxilliped with stout spines; and the strap-like epipods present on the third maxilliped and the first to fifth pereiopod.

The characters of the frontal region, chelipeds and walking legs suggest that Leslibetaeus, n. gen. is not closely related to any described alpheid genus. The symmetrical chelipeds, without snapping mechanism on the chela fingers, and with rows of setae on the mesial side of the carpus, as well as the imperfect orbital hoods, suggest that Leslibetaeus, n. gen. is probably a relatively basal genus. Five other alpheid genera are characterized by the equal and symmetrical chelipeds, with setae arranged in two or more rows on the mesial face of the cheliped carpus: Yagerocaris Kensley, 1988; Potamalpheops Powell, 1979; Stenalpheops Miya, 1997; Coutieralpheus Anker and Felder 2005; and Jengalpheops Anker \& Dworschak, in press. However, all these genera differ from Leslibetaeus, n. gen. in many other aspects, e.g., the presence of spines on the ischium/merus of the third and fourth pereiopod; the presence of a well developed rostrum (Yagerocaris, Potamalpheops, Coutieralpheus); and the sixth abdominal somite with an articulated plate (all but Yagerocaris) (cf. Kensley, 1988; Powell, 1979; Hobbs, 1983; 

have close affinities with Leslibetaeus, n. gen.

Leslibetaeus, n. gen. shares with Betaeus Dana, 1852 and Orygmalpheus De Grave and Anker, 2000 the symmetrical (or subsymmetrical) chelipeds, and the frontal margin devoid of rostrum and orbital hoods, but differs from those genera in the position of the dactylus on the chela, and in the features on the third maxilliped, third and second pereiopods, sixth abdominal somite etc. (cf. Hart, 1964; De Grave \& Anker, 2000). Despite a very superficial resemblance (symmetrical chelipeds carried extended and frontal margin without rostrum and orbital teeth) between Betaeus and Leslibetaeus, $\mathrm{n}$. gen., these two genera are not closely related. Leslibetaeus, n. gen. also has common features with Metabetaeus Borradaile, 1898 and Thuylamea Xuan, 2001, e.g., the symmetrical chelipeds and the absence of an articulated plate on the sixth abdominal somite, but differs greatly from those genera in the cheliped shape and the configuration of the frontal margin (cf. Banner \& Banner, 1960; Xuan, 2001). A close relationship between Leslibetaeus, n. gen. and Automate De Man, 1888, Alpheopsis Coutière, 1896 or any other genus present in the eastern Pacific is also unlikely. Thus the phylogenetic affinities of Leslibetaeus, n. gen. are rather enigmatic. The finding of a completely new taxon in a relatively accessible habitat indicates a potentially high biodiversity of the Isla Coiba National Park, which remains to be explored.

\section{Acknowledgments}

We would like to thank Leslie Harris (Natural History Museum of Los Angeles County, Los Angeles, USA), who contributed in the collection of the present material. ISW is grateful to Dr. Peter W. Glynn (University of Miami, The Rosenstiel School, USA) who invited him to participate in his project activities (March 2005) in Panama. The present study was supported by Dr. Nancy Knowlton (Scripps Institution of Oceanography, La Jolla, USA) in form of a Smithsonian Institution's postdoctoral fellowship to the first author (AA), and was accomplished in the Smithsonian Tropical Research Institution (STRI) facilities at Naos laboratory in Panama City, Republic of Panama. We also thank two anonymous reviewers whose suggestions and remarks improved the quality of the manuscript.

\section{Literature cited}

Abele, L.G. (1975) The macruran decapod Crustacea of Malpelo Island. Smithsonian Contributions to Zoology, 176, 69-85.

Abele, L.G. \& Kim, W. (1989) The decapod crustaceans of the Panama Canal. Smithsonian Contributions to Zoology, 482, 1-50.

Alvarez, F., Camacho, M.E. \& Villalobos, J.L. (1996) The first species of Prionalpheus from the 
eastern Pacific, and new records of caridean shrimp (Crustacea: Decapoda: Caridea) from the western coast of Mexico. Proceedings of the Biological Society of Washington, 109(4), 715724.

Anker, A. \& Dworschak, P.C. (in press) Jengalpheops rufus, gen. nov., sp. nov., a new commensal alpheid shrimp from the Philippines (Crustacea: Decapoda). Zoological Studies.

Anker, A. \& Felder, D.L. (2005) Description of Coutieralpheus setirostris, new genus, new species, an infaunal alpheid shrimp (Crustacea, Decapoda) from Florida, U.S.A. Crustacean Research, $34,40-52$.

Banner, A.H. \& Banner, D.M. (1960) Contributions to the knowledge of the alpheid shrimp of the Pacific Ocean, part VII: On Metabetaeus Borradaile, with a new species from Hawaii. Pacific Science, 15(3), 299-303.

Boone, L. (1931) A collection of anomuran and macruran Crustacea from the Bay of Panama and the fresh waters of the Canal zone. Bulletin of the American Museum of Natural History, 63(2), 137-189.

Carvacho, A. (1989) Les crevettes carides du Golfe de Californie IV. Alpheus confusus n. sp. Crustaceana, 56(1), 58-61.

Chace, F.A. Jr. (1937) Caridean decapod Crustacea from the Gulf of California and the west coast of Lower California. Part VII. In: The Templeton Crocker Expedition. Zoologica, New York Zoological Society, 22(8), 109-138.

Chace, F.A. Jr. (1962) The non-brachyuran decapod crustaceans of Clipperton Island. Proceedings of the United States National Museum, 113(3466), 605-635.

Christoffersen, M.L. \& Ramos, G.E. (1987) A new snapping shrimp (Caridea, Alpheidae) from the Pacific coast of Colombia. Revista Biología Tropical, 35, 333-338.

Christoffersen, M.L. \& Ramos, G.E. (1988) A new species of Alpheus (Caridea, Alpheidae) from the Pacific coast of Colombia. Revista Nordestina de Biologia, 6, 61-65.

Coutière, H. (1900) Sur quelques Alpheidae des côtes américaines (Collection de l'United States National Museum Washington). Comptes Rendus Hebdomadaires des Séances de l'Académie des Sciences, 131, 356-358.

Coutière, H. (1909) The American species of snapping shrimps of the genus Synalpheus. Proceedings of the United States National Museum, 36(1659), 1-93.

De Grave, S. \& Anker, A. (2000) A new genus and new species of alpheid shrimp (Crustacea: Decapoda) from Papua New Guinea. Raffles Bulletin of Zoology, 48(2), 249-256.

Felder, D.L., Nates, S.F. \& Robles, R.R. (2003) Hurricane Mitch: Impacts of bioturbating crustaceans in shrimp ponds and adjacent estuaries of coastal Nicaragua. Open File Report 03-179, $1-70$.

Hart, J.F.L. (1964) Shrimps of the genus Betaeus on the Pacific coast of North America with descriptions of three new species. Proceedings of the United States National Museum, 115, 431-466.

Hermoso-Salazar, A.M., Wicksten, M. \& Morrone, J.J. (2005) Redescriptions and taxonomic notes on species of the Synalpheus townsendi Coutière, 1909 complex (Decapoda: Caridea: Alpheidae). Zootaxa, 1027, 1-26.

Hobbs, H.H. Jr. (1983) The African shrimp genus Potamalpheops in Mexico (Decapoda: Alpheidae). Crustaceana, 44(2), 221-224.

Holthuis, L.B. (1952) Avdelningen The Crustacea Decapoda Macrura of Chile. Reports of the Lund University Chile Expedition 1948-49, $\mathrm{N}^{\circ}$ 5. Lunds Universitets Årsskrift, Nyi Föijd (new series), Avdelningen, 2, 47(10), 1-110.

Holthuis, L.B. (1980) Alpheus saxidomus new species, a rock-boring snapping shrimp from the Pacific coast of Costa Rica, with notes on Alpheus simus Guérin-Méneville, 1856. Zoologische Mededelingen, 55, 47-58.

Kensley, B.F. (1988) New species and records of cave shrimps from the Yucatan Peninsula (Deca- 
poda: Agostocarididae and Hippolytidae). Journal of Crustacean Biology, 8, 688-699.

Kim, W. \& Abele, L.G. (1988) The snapping shrimp genus Alpheus from the eastern Pacific (Decapoda; Caridea: Alpheidae). Smithsonian Contributions to Zoology, 454, 1-119.

Knowlton, N. \& Mills, D.K. (1992) The systematic importance of colour and colour pattern: evidence for complexes of sibling species of snapping shrimp (Caridea: Alpheidae: Alpheus) from the Caribbean and Pacific coasts of Panama. Proceedings of the San Diego Society of Natural History, 18, 1-5.

McClure, M.R. \& Wicksten, M.K. (2000) Alpheus Taxonomic studies of snapping shrimp of the Alpheus "edwardsii" group from the Galapagos Islands. Proceedings of the Biological Society of Washington, 113(4), 964-973.

Méndez, M.G. \& Wicksten, M.K. (1982) Notalpheus imarpe: a new genus and species of snapping shrimp from western South America (Decapoda: Alpheidae). Proceedings of the Biological Society of Washington, 95(4), 709-713.

Miya, Y. (1997) Stenalpheops anacanthus, new genus, new species (Crustacea, Decapoda, Alpheidae) from the Seto Inland Sea and the Sea of Ariake, South Japan. Bulletin of Faculty of Liberal Arts, Nagasaki University, 38(1), 145-161.

Powell, C.B. (1979) Three alpheid shrimps of a new genus from West African fresh and brackish waters: taxonomy and ecological zonations (Crustacea Decapoda Natantia). Revue de Zoologie Africaine, 93(1), 116-150.

Ramos, G.E. (1997) Alpheus agrogon, a new species of alpheid shrimp (Decapoda: Alpheidae) from Gorgona Island, Pacific coast of Colombia. Revista de Biología Tropical, 44(3)-45(1), B, 395400.

Ramos, G.E. \& Von Prahl, H. (1989) Alpheus utriensis, new species (Caridea: Alpheidae) from Utria Sound, Pacific Coast of Colombia. Journal of Crustacean Biology, 9, 477-481.

Ríos, R. (1992) Camarones carideos del Golfo de California. VI. Alpheidae del estuario de Mulegé y de Bahía Concepción, Baja California Sur, México (Crustacea: Caridea). Proceedings of San Diego Society of Natural History, 14, 1-13.

Ríos, R. \& Carvacho, A. (1983a) Caridean shrimps of the Gulf of California. I. New records, with some remarks on amphi-American distribution. Pacific Science, 36(4), 459-465.

Ríos, R. \& Carvacho, A. (1983b.) Leptalpheus mexicanus, new species (Crustacea, Decapoda, Alpheidae). Caridean shrimps of the Gulf of California III. Journal of Crustacean Biology, 3(2), 306-313.

Wicksten, M.K. (1981) The species of Automate (Caridea: Alpheidae) in the eastern Pacific Ocean. Proceedings of the Biological Society of Washington, 94(4): 1104-1109.

Wicksten, M.K. (1983) A monograph on the shallow-water caridean shrimps of the Gulf of California, Mexico. Allan Hancock Foundation Monographs, 13, 1-59.

Wicksten, M.K. (1988) A new species of snapping shrimp from the Pacific coast of Colombia (Decapoda, Caridea, Alpheidae). Crustaceana, 54(1), 1-4.

Wicksten, M.K. (1989) Synalpheus arostris and Philocheras lapillus, two new species of caridean shrimps from the tropical eastern Pacific. Proceedings of the Biological Society of Washington, 102(1), 78-83.

Wicksten, M.K. (1990) On the status of Alpheus barbara Lockington (Crustacea: Caridea: Alpheidae). Proceedings of the Biological Society of Washington, 103(1), 100-102.

Wicksten, M.K. (1992) A new species of Alpheopsis (Decapoda, Alpheidae) from the tropical eastern Pacific, with a key to the species of Alpheopsis of the Americas. Crustaceana, 63(1), 5156.

Wicksten, M.K. (1993) Caridean and stenopodid shrimp of the Galapagos Islands. In: James, M.J. (Ed.), Galapagos Marine Invertebrates. Chapter 6. Plenum, New York, 147-156 pp.

Wicksten, M.K. (1994a) Taxonomic remarks on two species of the genus Synalpheus from the tropical eastern Pacific (Decapoda, Alpheidae). Bulletin du Muséum National d'Histoire Naturelle, 
série 4, section A, 16(1), 209-212.

Wicksten, M.K. (1994b) On the identity of snapping shrimp described and identified by W.N. Lockington, 1878. Bulletin of South California Academy of Sciences, 93, 110-117.

Wicksten, M.K. (1999) A new genus and species of alpheid shrimp (Caridea: Alpheidae) from the Galapagos Islands. Crustacean Research, 28, 104-111.

Wicksten, M.K. \& Hendrickx, M.E. (1986) Alpheopsis cortesiana, a new snapping shrimp from the Gulf of California. Proceedings of the Biological Society of Washington, 99(2), 196-197.

Xuan, N.V. (2001) A new alpheid shrimp (Crustacea: Decapoda: Alpheidae) from South Vietnam. Zoologische Mededelingen, Leiden, 75(1-15), 217-228. 